OPEN ACCESS

Edited by:

Lixing Huang,

Jimei University, China

Reviewed by:

Peng Luo,

South China Sea Institute of

Oceanology (CAS), China

Xueming Dan

South China Agricultural

University, China

*Correspondence:

Youlu Su

youlusu@zhku.edu.cn

Specialty section:

This article was submitted to Veterinary Infectious Diseases,

a section of the journal

Frontiers in Veterinary Science

Received: 30 August 2020 Accepted: 21 December 2020

Published: 20 January 2021

Citation:

Wang B, Mao C, Feng J, Li Y, Hu J, Jiang B, Gu Q and Su Y (2021) A First Report of Aeromonas veronii Infection of the Sea Bass, Lateolabrax maculatus in China.

Front. Vet. Sci. 7:600587.

doi: 10.3389/fvets.2020.600587

\section{A First Report of Aeromonas veronii Infection of the Sea Bass, Lateolabrax maculatus in China}

\author{
Baotun Wang 1,2,3, Can Mao ${ }^{2}$, Juan Feng ${ }^{2}$, Yong $\mathrm{Li}^{4}$, Jianmei $\mathrm{Hu}^{1,2,3}$, Biao Jiang ${ }^{1}$, \\ Qunhong $\mathrm{Gu}^{4}$ and Youlu $\mathrm{Su}{ }^{1,4 *}$ \\ ${ }^{1}$ Innovative Institute of Animal Healthy Breeding, Zhongkai University of Agriculture and Engineering, Guangzhou, China, \\ ${ }^{2}$ Key Laboratory of South China Sea Fishery Resources Development and Utilization, Ministry of Agriculture and Rural Affairs, \\ Guangzhou, China, ${ }^{3}$ National Demonstration Center for Experimental Fisheries Science Education, Shanghai Ocean \\ University, Shanghai, China, ${ }^{4}$ Modern Agricultural Development Center of Zhuhai City, Zhuhai, China
}

The sea bass, Lateolabrax maculatus is commercially farmed in Zhuhai, located in the Guangdong Province of China. L. maculatus in aquaculture have suffered acute death, characterized by ulcerations on the body surface, congestion, and hemorrhage in internal organs such as liver, kidney, and spleen. The dominant infecting strain of bacteria isolated from the kidneys of diseased fish was identified as Aeromonas veronii (strain 18BJ181). This identification was based on analysis of morphological, physiological, and biochemical features, as well as $16 \mathrm{~S}$ rRNA and gyrB gene sequences. Drug sensitivity testing showed that the strain 18BJ181 isolate was resistant to four antibacterial drugs, including amoxicillin, madinomycin, penicillin and sulfamethoxazole, while moderately sensitive to erythromycin and rifampicin. The detection of growth characteristics showed that the strain 18BJ181 exhibited adaptability to the environment. In addition, some virulence genes, such as aer, act, gcaT, tapA and fla, were detected in the strain 18BJ181. The median lethal dosage of the strain 18BJ181 isolate in L. maculatus was $8.5 \times 10^{5}$ and $4.2 \times 10^{5} \mathrm{cfu} / \mathrm{g}$ under the conditions of intraperitoneal injection and intramuscular injection, respectively. The experimentally induced infection showed that the 18BJ181 isolate caused considerable histological lesions in L. maculatus, including tissue degeneration, necrosis, and different degrees of hemorrhage. These results provided evidence for a more comprehensive understanding of $A$. veronii strain 18BJ181 infection in L. maculatus.

Keywords: Aeromonas veronii, Lateolabrax maculatus, physiological and biochemical characteristics, pathogenicity, pathology

\section{INTRODUCTION}

Aeromonas veronii, a Gram-negative bacterial pathogen, has a wide range of hosts and can cause diarrhea and sepsis in humans (1). In particular, A. veronii is a common pathogen in aquaculture, which can infect a variety of aquatic animals, including freshwater goldfish (Carassius auratus) (2), Nile tilapia (Oreochromis niloticus,) (3), Chinese Longsnout catfish (Leiocassis longirostris günther) (4) and catfish (Ictalurus punctatus,) $(5,6)$. The clinical symptoms of infected fish are skin ulcers and visceral hemorrhage. The histopathological changes caused by $A$. veronii are manifested as 
cerebral vascular hyperemia, inflammatory cell infiltration, osteoporosis, renal tubular necrosis, and hepatocyte degeneration (7). The virulence of $A$. veronii was shown to be stronger than Aermonas hydrophila, which could cause septicemia in fish (8). At present, A. veronii is the primary pathogen isolated from freshwater fish in South China.

The sea bass, Lateolabrax maculatus, is an economically important, cultured species in East Asia and is an important aquaculture fish in China in particular (9). Viral and bacterial diseases can cause significant damage to cultured L. maculatus $(10,11)$. In 2018 , a continuous epidemiological investigation was carried out in the L. maculatus culture area in the Zhuhai, Guangdong Province in China, and found that A. veronii was an important pathogen. In this study, the results of isolation, identification, drug sensitivity, growing characteristics, virulence gene distribution and pathogenicity of the $A$. veronii isolate are described.

\section{MATERIALS AND METHODS}

\section{Sampling of Diseased Fish and Isolation of Bacteria}

Diseased L. maculatus were sampled from a freshwater fish farm in Zhuhai, Guangdong Province, China. Moribund fish were taken from the pond to a laboratory at the Modern Agricultural Development Center of Zhuhai City, Zhuhai, Guangdong Province, China. Only diseased fish with typical clinical symptoms were used for bacterial examination. The fish were dissected after their skin was cleaned with 75\% ethyl alcohol. Liver, spleen, and kidney were used for bacterial isolation. A Nutrient Agar medium (NA) was employed for bacteria isolation for $24 \mathrm{~h}$ at $28^{\circ} \mathrm{C}$ and the dominant uniform bacterial colonies were purified by streaking onto the NA plates twice. A single bacterial colony was selected and inoculated in nutrient broth (NB) for $14 \mathrm{~h}$ at $28^{\circ} \mathrm{C}$, then preserved at $-80^{\circ} \mathrm{C}$ in the $\mathrm{NB}$ medium containing $20 \%(\mathrm{v} / \mathrm{v})$ sterile glycerol. A dominant strain was tentatively named 18BJ181.

\section{Analysis of Physiological and Biochemical Characterization}

Thirty-eight biochemical reactions were performed using Vitek 2 Compact (Biomerieux, France) according to the manufacturer's instructions. Identification results of bacterial species were generated based on the combination of biochemical activities.

\section{Sequence Analysis of $16 \mathrm{~S}$ rRNA and gyrB Gene}

The genomic DNA of the strain 18BJ181 was extracted using a TIANamp Bacterial DNA Kit (Tiangen-Biotech, Beijing, China) following the manufacturer's guidelines. Genomic DNA was stored at $-20^{\circ} \mathrm{C}$. A pair of universal primers, 8 F:5' - AGAGTTTGATCCTGGCTCAG-3' and 1492 R: 5'-GGTTACCTTGTTACGACTT-3', was used for amplification of the $16 \mathrm{~S}$ rRNA gene. A pair of primers, $3 \mathrm{~F}: 5^{\prime}$ TCCGGCGGTCTGCACGGCGT- $3^{\prime}$ and 14 R: $5^{\prime}$-TTGTCCGGG TTGTACTCGTC-3', was used for amplification of the $g y r B$ gene. The mixtures were incubated in a cycle of $95^{\circ} \mathrm{C}$ for $5 \mathrm{~min}$ followed by $30 \mathrm{cycles}$ of $95^{\circ} \mathrm{C}$ for $15 \mathrm{~s}, 55^{\circ} \mathrm{C}$ for $15 \mathrm{~s}$, and $72^{\circ} \mathrm{C}$ for $15 \mathrm{~s}$, and extension at $72^{\circ} \mathrm{C}$ for $10 \mathrm{~min}$. The amplified products were observed and sequenced, then were sent to Guangzhou Tian Yihui Gene Technology Co., Ltd. A BLAST search for sequences was carried out via the NCBI website (https://www. ncbi.nlm.nih.gov/). The phylogenetic trees were established using the Neighbor-joining method in the MEGA 5.1 software package (12).

\section{Growing Characteristics}

The $\mathrm{pH}$ value and $\mathrm{NaCl}$ concentration were adjusted based on the NB medium. Before sterilization by autoclaving, the $\mathrm{pH}$ was adjusted to the desired values with $\mathrm{NaOH}(1 \mathrm{~mol} / \mathrm{L})$ or $\mathrm{HCl}(1$ $\mathrm{mol} / \mathrm{L})$. The target salinity values were obtained by adding $\mathrm{NaCl}$ to NB. The isolate cultured in NB was incubated at $28^{\circ} \mathrm{C}$ with $\mathrm{pH}$ value of $3,5,7,9$, and 11 to evaluate growth characteristics. Similarly, the growth characteristics of the isolate was evaluated in $\mathrm{NB}$ at $28^{\circ} \mathrm{C}$ with a salinity of $5,10,20,40$, and $80 \mathrm{ppt}$, respectively. All flasks were inoculated with $0.2 \mathrm{~mL}$ of bacterial suspension (optical density, $\mathrm{OD}_{600}=0.1$ ) and cultured at $180 \mathrm{rpm}$ in 96 -well plates. Growth was monitored for $23 \mathrm{~h}$ by measuring the OD with a micrometer at $600 \mathrm{~nm}$ every $1 \mathrm{~h}$.

\section{Antimicrobial Resistance Test}

The antibiotic resistance of the strain 18BJ181 was determined by the disk diffusion method [K-B method (13)]. The strain $18 \mathrm{BJ} 181$ was cultured in Mueller-Hinton medium and the concentration of the bacterial solution was adjusted to $1 \times 10^{8} \mathrm{cfu} / \mathrm{ml}$. The suspension was spread on MuellerHinton agar containing either trimethoprim, amoxicillin, chloramphenicol, doxycycline, erythromycin, enrofloxacin, florfenicol, furazolidone, gentamicin, madinomycin, neomycin, norfloxacin, oxytetracycline, penicillin, rifampicin or sulfamethoxazole (all purchased from Hangzhou microbial Reagent Co. Ltd). According to the size of the bacteriostatic zone, the results of drug sensitivity were judged by sensitivity, mediating, and drug resistance.

\section{Virulence Genes Detection}

Conventional PCR assays for the amplification of the aerolysin (aer), cytotoxic enterotoxin (act), heat-stable enterotoxin (ast), glycerophospholipid-cholesterol acyltransferase (gcaT), extracellular deoxyribonuclease (exu), Type IV pilus (tapA), lip and flagellin $(f l a)$ were performed with the template DNA of the strain 18BJ181. Primers used for amplification of the eight genes are shown in Table 1. Each PCR reaction contained $12.5 \mu \mathrm{l}$ of PCR Mix (Tiangen Biotech, Beijing Co., Ltd., China), $1 \mu$ l of each paired primer, $1 \mu \mathrm{l}$ of template DNA, and $9.5 \mu \mathrm{l}$ of $\mathrm{ddH}_{2} \mathrm{O}$. The PCR reaction commenced with denaturation at $94^{\circ} \mathrm{C}$ for $2 \mathrm{~min}$, then 35 cycles of amplification, and finally extension at $72^{\circ} \mathrm{C}$ for $10 \mathrm{~min}$. Each cycle consisted of denaturation at $94^{\circ} \mathrm{C}$ for $30 \mathrm{~s}$, annealing for $50 \mathrm{~s}$ and extension at $72^{\circ} \mathrm{C}$ for $30 \mathrm{~s}$ (Table 1). The amplified PCR products were maintained at $4^{\circ} \mathrm{C}$. The results were recorded after electrophoresis on $2 \%$ agarose gel stained with ethidium bromide and the positive product of PCR were 
TABLE 1 | The information for the eight virulence genes pairs of primers.

\begin{tabular}{|c|c|c|c|}
\hline $\begin{array}{l}\text { Target } \\
\text { gene }\end{array}$ & Primer sequence $\left(5^{\prime}-3^{\prime}\right)$ & $\begin{array}{l}\text { Product size } \\
\text { (bp) }\end{array}$ & $\mathrm{T}_{\mathrm{m}}\left({ }^{\circ} \mathrm{C}\right)$ \\
\hline aer & $\begin{array}{l}\text { F: TCTCCATGCTTCCCTTCCACT } \\
\text { R: CCAGTTCCAGTCCCACCACT }\end{array}$ & 431 & 63 \\
\hline act & $\begin{array}{l}\text { F: AGAAGGTGACCACCACCAAGAACA } \\
\text { R: AACTGACATCGGCCTTGAACTC }\end{array}$ & 232 & 65 \\
\hline ast & $\begin{array}{l}\text { F: TCTCCATGCTTCCCTTCCACT } \\
\text { R: GTGTAGGGATTGAAGAAGCCG }\end{array}$ & 331 & 63 \\
\hline gсат & $\begin{array}{l}\text { F: CTCCTGGAATCCCAAGTATCAG } \\
\text { R: GGCAGGTTGAACAGCAGTATCT }\end{array}$ & 237 & 65 \\
\hline$e x u$ & $\begin{array}{l}\text { F: AGACATGCACAACCTCTTCC } \\
\text { R: GATTGGTATTGCCTTGCAAG }\end{array}$ & 323 & 61 \\
\hline $\operatorname{tap} A$ & $\begin{array}{l}\text { F: ATGACCTCTAGCCCCAATA } \\
\text { R: ACCCGATTGATTTCTGCC }\end{array}$ & 550 & 55 \\
\hline lip & $\begin{array}{l}\text { F: ATCTTCTCCGACTGGTTCGG } \\
\text { R: CCGTGCCAGGACTGGGTCTT }\end{array}$ & 382 & 63 \\
\hline fla & $\begin{array}{l}\text { F: TCCAACCGTYTGACCTC } \\
\text { R: GMYTGGTTGCGRATGGT }\end{array}$ & 608 & 55 \\
\hline
\end{tabular}

sent to were sent to Guangzhou Tian Yihui Gene Technology Co., Ltd for analysis and verification $(14,15)$.

\section{Fish Infection Experiments}

The L. maculatus weighing approximately $18 \mathrm{~g}$ were cultured in aerated ponds at the Zhuhai experimental base of the South China Sea fisheries Research Institute of the Chinese Academy of Fishery Sciences, Guangzhou, China. The water temperature was controlled at $28 \pm 1{ }^{\circ} \mathrm{C}$. During the temporary feeding period, fish were fed a basal diet of $5 \%$ body weight at 7 am and 6 pm every day. After feeding for $15 \mathrm{~min}$, the residual feed was removed to prevent the water from becoming contaminated and fish were temporarily reared for a week. Before the experiment, three fish were randomly selected for visceral bacteriological examination and gill parasite monitoring. A. veronii was transferred to $\mathrm{NB}$ medium at $5 \%$ and cultured for $10 \mathrm{~h}$ at $28^{\circ} \mathrm{C}$ and 200 $\mathrm{rpm} / \mathrm{min}$. The concentration of bacterial suspension was adjusted to $3.9 \times 10^{9}, 3.9 \times 10^{8}, 3.9 \times 10^{7}, 3.9 \times 10^{6}$ and $3.9 \times 10^{5} \mathrm{cfu} / \mathrm{ml}$, respectively. Three hundred healthy $L$. maculatus were randomly selected. Eugenol was used to anesthetize the L. maculatus before infection. Intraperitoneal injection and intramuscular injection was carried out using $0.1 \mathrm{ml}$ of the above different concentrations of the bacterial suspension. The control group received an intraperitoneal injection and intramuscular injection of an equal volume of $0.85 \%$ normal saline. Bacteria from the liver, spleen, and ascites fluid of experimentally infected fish were re-isolated. All protocols for experiments involving live animals conducted in this study were approved by the Animal Care and Use Committee of Zhongkai University of Agriculture and Engineering, Guangzhou, China.

\section{Histopathological Examination}

Heart, liver, kidney and spleen tissue from the moribund fish after infection were fixed in $10 \%$ buffered formalin solution, dehydrated in ethanol, embedded in paraffin wax blocks and sectioned, then stained with hematoxylin and eosin for histopathological observation.

\section{RESULTS}

\section{Clinical Symptoms of Naturally Infected Fish}

The L. maculatus naturally infected with $A$. veronii typically show acute death in aquaculture conditions. After 2-3 days of infection, fish begin to swim slowly leading to high mortality (Figure 1A). Some diseased fish exhibit large areas of ulceration on the body surface, limited to the surface of the skin (Figure 1B). After dissecting the fish, it was found that there were mild ascites in the abdomen. Hemorrhage of internal organs and intestinal inflammation were often observed (Figure 1C). Some fish showed typical clinical lesions, as well as swelling and hemorrhage of the kidney (Figure 1D), ischemia and hemorrhage in the liver, and darkening of the spleen (Figure 1E).

\section{Physiological and Biochemical Characteristics of the Bacteria}

The strain $18 \mathrm{BJ} 181$ is a typical gram-negative bacterium isolated directly from diseased L. maculatus. Physiological and biochemical results in this study showed that 16 biochemical reactions of the strain $18 \mathrm{BJ} 181$ were positive, such as Ala-Phe-Pro arylamidase, L-Proline arylamidase, and sucrose, while 22 biochemical reactions were negative, such as $\mathrm{H}_{2} \mathrm{~S}$ production and $\beta$-glucuronidase in a total of 38 biochemical reactions (Table 2). This species strain is distinguishable from the other three Aeromonas species [A. veronii $b v$. veronii, $A$. hydrophila, and A. caviae, (16]]. Due to the complexity of Aeromonas members and the limited number of biochemical reactions of Vitek 2, the test identified these isolates as Aeromonas species (probability $>99 \%$ ), but failed to correctly differentiate them to the species level.

\section{Phylogenetic Analyses of the 16S rRNA and gyrB Genes}

The gene sequences of different Aeromonas were downloaded from the NCBI database and a phylogenetic tree was constructed. The $16 \mathrm{~S}$ rRNA gene sequence of the strain $18 \mathrm{BJ} 181$ was $1,445 \mathrm{bp}$ in length. The BLAST alignments showed that it was most similar to strain A. vernoii XG31-1 (MF716697.1). The $\operatorname{gyr} B$ gene sequence of the strain 18 BJ181 was $1,045 \mathrm{bp}$ in length. The BLAST alignments showed that it was most similar to strain A. vernoii CB51 (CP015448.1). Identities were approximately 99.81\%. In addition, the results showed that the strain $18 \mathrm{BJ} 181$ was grouped with a cluster of known species of $A$. veronii strains according to phylogenetic trees established on the $16 \mathrm{~S}$ rRNA sequence and $g y r B$ sequence (Figure 2). Based on biochemical tests and phylogenesis through $16 \mathrm{~S}$ rRNA and gyrB 


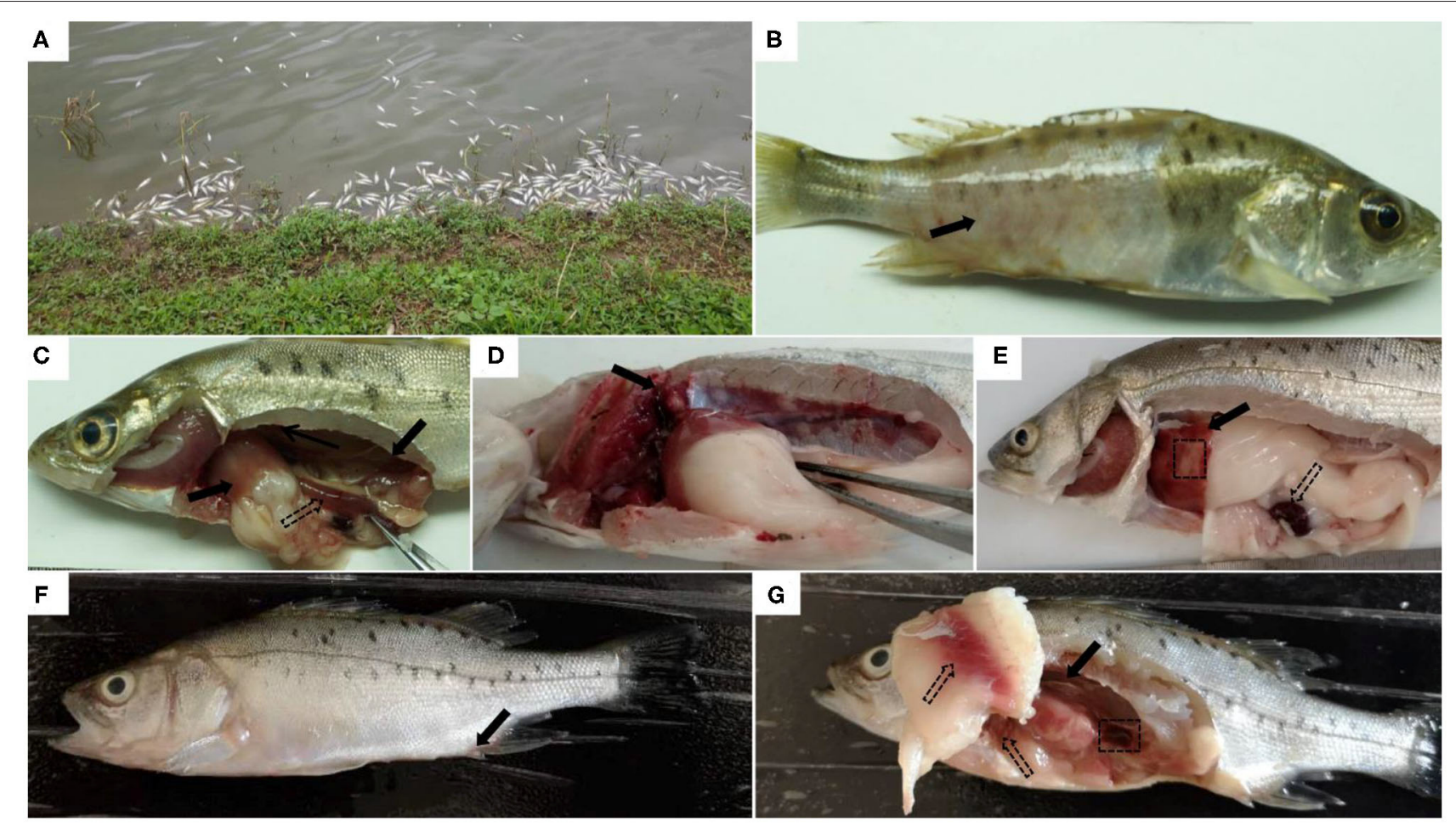

FIGURE 1 | Clinical symptoms of natural or artificial infection of Aeromonas veronii in Lateolabrax maculatus. Acute death of L. maculatus in fish farms (A). Obvious clinical symptoms of natural infection with A.veronii in diseased L.maculatus, such as ulceration on the body surface (solid arrow) (B), hemorrhages in internal organs (solid arrows) and intestinal inflammation (hollow arrows) (C), hemorrhage and swelling of the kidney (solid arrows) (D), liver with both ischemia (black box), hemorrhage (solid arrow) and darkened spleen (hollow arrows) (E). Clinical symptoms of L.maculatus artificially infected with A.veronii: the anal fin is slightly inflamed (solid arrow) (F), slightly darkened spleen (black box), congestion in the abdominal wall and liver (hollow arrows), and hemorrhage and swelling in the kidney (solid arrows) (G).

genes, the strain $18 \mathrm{BJ} 181$ was determined to be a member of Aeromonas veronii.

\section{Growth Characteristics of the Strain 18BJ181}

Growth characteristics of the strain 18BJ181 were tested (Figure 3). As shown in Figure 3A, growth was similar at salinity concentrations of 5, 10, 20, and 40 ppt. Growth was improved at 20 and $40 \mathrm{ppt}$ and significantly inhibited at a salinity of $80 \mathrm{ppt}$. In terms of $\mathrm{pH}$, as shown in Figure 3B, the growth of this isolate was maximal at an optimum of $\mathrm{pH}$ 7. The latent phase of growth was somewhat extended at $\mathrm{pH} 11$ and growth capacity was reduced. At $\mathrm{pH} 7$ and 9, the growth of the strain 18BJ181 showed that trends were similar, and considerable final concentrations were obtained. Growth was halted at pH 3.

\section{Drug Sensitivity}

The drug sensitivity results indicated that the strain 18BJ181 showed different sensitivities to 16 antibacterial drugs. Strain $18 \mathrm{BJ} 181$ was sensitive to 10 antibacterial drugs such as sulfamethoxazole, trimethoprim, and chloramphenicol, showed moderate sensitivity to erythromycin and rifampicin, and was resistant to amoxicillin, madinomycin, penicillin and sulfamethoxazole (Table 3 ).

\section{Virulence Factors}

The PCR profiles of eight virulence genes screened in this study showed that five genes (aer, act, gcaT, $\operatorname{tap} A$, and $f l a)$ was present in the strain 18BJ181 isolate (Figure 4).

\section{Experimental Infections}

L. maculatus can be infected successfully by intraperitoneal injection and intramuscular injection (Figure 5). The results showed that mortality of L. maculatus occurred within $24 \mathrm{~h}$, and the number of deaths decreased significantly within a $48 \mathrm{~h}$ period. When the concentration of intraperitoneal injection and intramuscular injection was $2.2 \times 10^{7} \mathrm{cfu} / \mathrm{g}$, the mortality rate of the fish reached $100 \%$. When the infection concentration was $2.2 \times 10^{6} \mathrm{cfu} / \mathrm{g}$, the mortality rate for intraperitoneal injection and intramuscular injection was 83.3 and $87.5 \%$, respectively. Using an infection concentration of $2.2 \times 10^{5} \mathrm{cfu} / \mathrm{g}$, the mortality rate for intraperitoneal injection and intramuscular injection was 4 and $25 \%$, respectively. When the infection concentrations were $2.2 \times 10^{4} \mathrm{cfu} / \mathrm{g}$ and $2.2 \times 10^{3} \mathrm{cfu} / \mathrm{g}$, respectively, fish with intraperitoneal injection did not die and the mortality rate of fish infected by intramuscular injection was also very low, no more than 5\%. The median lethal dosage $\left(\mathrm{LD}_{50}\right)$ through intraperitoneal injection and intramuscular injection was calculated by Karber's method as $8.5 \times 10^{5}$ and $4.2 \times 10^{5}$ $\mathrm{cfu} / \mathrm{g}$, respectively. 
TABLE 2 | Biochemical characterization of the strain 18BJ181 from naturally infected Lateolabrax maculatus in GuangDong province using Vitek 2 compact.

\begin{tabular}{|c|c|c|c|c|}
\hline Characteristics & 18BJ181 & $\begin{array}{l}\text { Aeromonas veronii } \\
\text { ATCC9071 }\end{array}$ & $\begin{array}{l}\text { Aeromonas hydrophila } \\
\text { CGMCC1.2017 }\end{array}$ & $\begin{array}{c}\text { Aeromonas caviae } \\
\text { CGMCC1.1960 }\end{array}$ \\
\hline Ala-Phe-Pro arylamidase & + & - & + & - \\
\hline$\beta$-glucoronidase & - & - & - & - \\
\hline L-Proline arylamidase & + & + & + & + \\
\hline Sucrose & + & + & + & + \\
\hline Glycine arylamidase & + & - & - & + \\
\hline O/129 resistance & + & + & + & + \\
\hline$\beta$-Galactosidase & + & + & + & + \\
\hline D-Maltose & + & + & + & + \\
\hline Lipase & - & + & + & + \\
\hline Succinate alkalinisation & + & + & + & + \\
\hline L-Malate assimilation & - & - & - & + \\
\hline D-Glucose & + & + & + & + \\
\hline D-Mannose & + & + & + & - \\
\hline Tyrosine arylamidase & + & + & + & + \\
\hline Citrate & - & + & - & - \\
\hline$\beta$-N-Acetyl-glucosaminidase & - & + & + & + \\
\hline Ellman & + & + & + & + \\
\hline D-Cellobiose & - & + & - & + \\
\hline Courmarate & + & + & - & + \\
\hline
\end{tabular}

The results of 12 biochemical reactions including adonitol, D-tagatose, L-pyrrolydonyl-arylamidase, glutamyl arylamidase pNA, Iysine decarboxylase, L-arabitol, L-histidine assimilation, $\gamma$-glutamyl-transferase, $\beta$-xylosidase, urease, malonate and $\alpha$-glucosidase of the strain 18BJ181 and reference Aeromonas were all negative (16).

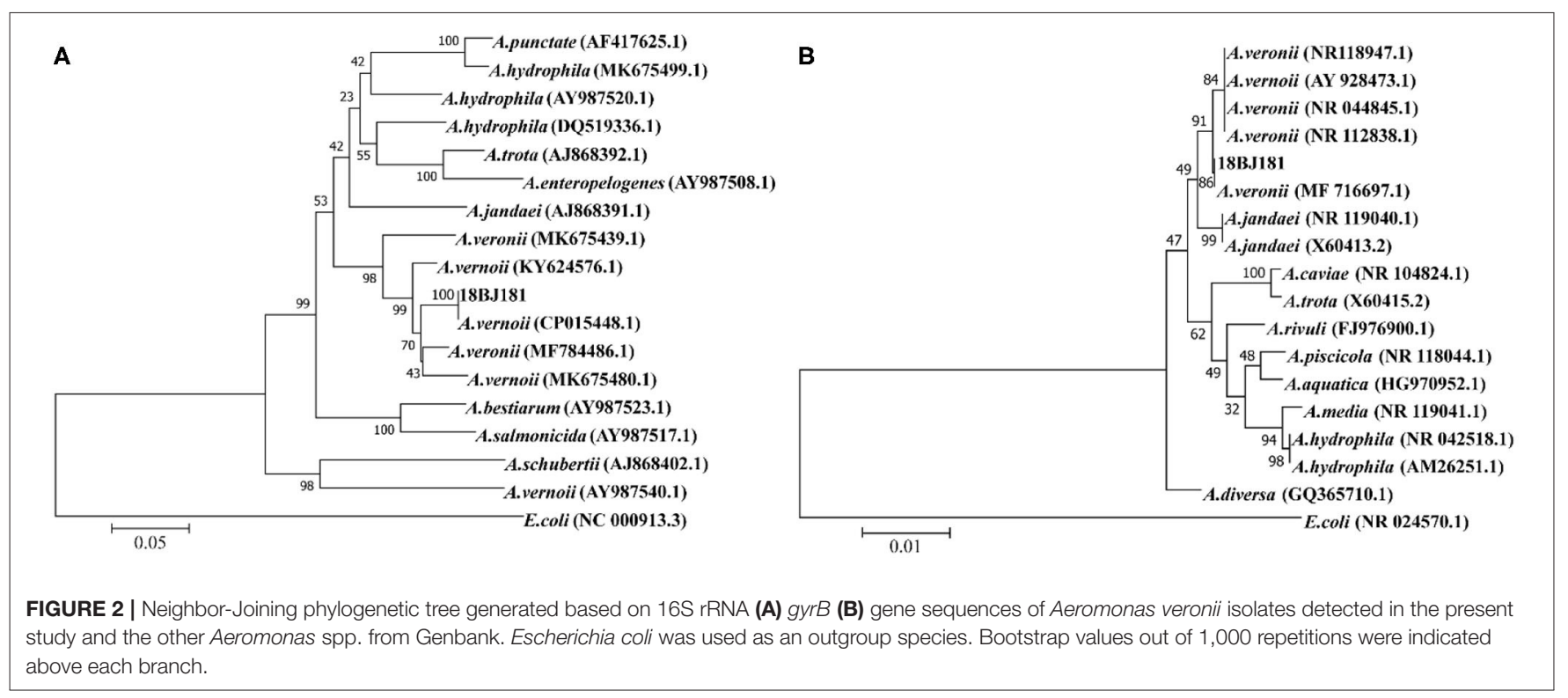




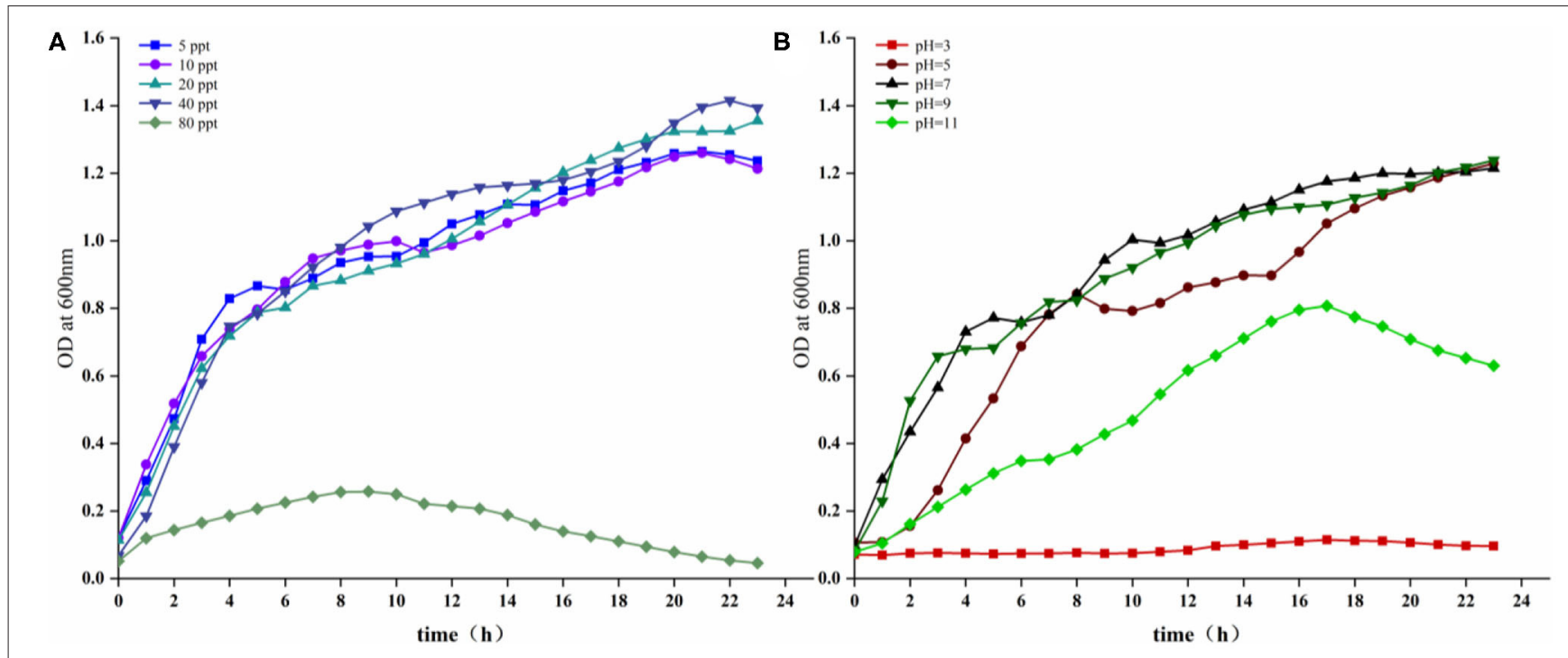

FIGURE 3 | Growing characteristics of the strain 18BJ181. Growth under the conditions of different salinity (A), different pH (B).

TABLE 3 | Antibiotic sensitivity of the strain 18BJ181.

\begin{tabular}{lcl}
\hline Antibiotics & Content (ug/disc) & Sensitivity \\
\hline Sulfamethoxazole and Trimethoprim & 1.25 & $\mathrm{~S}$ \\
Amoxicillin & 20 & $\mathrm{R}$ \\
Chloramphenicol & 30 & $\mathrm{~S}$ \\
Doxycycline & 30 & $\mathrm{~S}$ \\
Erythromycin & 15 & $\mathrm{M}$ \\
Enrofloxacin & 30 & $\mathrm{~S}$ \\
Florfenicol & 30 & $\mathrm{~S}$ \\
Furazolidone & 100 & $\mathrm{~S}$ \\
Gentamicin & 10 & $\mathrm{~S}$ \\
Madinomycin & 30 & $\mathrm{R}$ \\
Neomycin & 10 & $\mathrm{~S}$ \\
Norfloxacin & 10 & $\mathrm{~S}$ \\
Oxytetracycline & 30 & $\mathrm{~S}$ \\
Penicillin & 10 & $\mathrm{R}$ \\
Rifampicin & 5 & $\mathrm{M}$ \\
Sulfamethoxazole & 300 & $\mathrm{R}$
\end{tabular}

$S$, sensitive, $M$, moderately susceptible, $R$, resistant.

\section{Pathological Analysis of Artificially Infected Fish}

There were no obvious lesions on the body surface of $L$. maculatus that were artificially infected with the strain 18BJ181 isolate. The predominant symptoms were redness and swelling of the anal fin (Figure 1F). After dissection of the infected fish, it was observed that the ascites fluid in the abdominal cavity increased significantly. The abdominal wall and liver were congested. Kidney enlargement and hemorrhage were observed, and the spleen became darker in color (Figure 1G).
The histopathology of L. maculatus infected by intraperitoneal injection of $A$. veronii was as follows: cardiomyocyte vacuolization with myofibrillar degeneration was observed in the heart (Figure 6A), the liver showed different levels of hepatocellular steatosis, congestion, and hemorrhage (Figure 6C), the renal tubular epithelial lining was severely necrotic, and detached from the basement membrane, and interstitial tissue hemorrhage was evident (Figure 6E), and moderate splenitis was observed with numerous lymphocytes and macrophages aggregated around ellipsoids, in addition to an accumulation of a proteinaceous substance accumulated in the spleen (Figure 6G). The histopathological changes of L. maculatus infected by intramuscular injection were as follows: myocardial hemorrhage with myofibrillar edema, rupture, and necrosis was observed in the heart (Figure 6B), the liver had histopathological changes such as hepatocellular steatosis, congestion, and inflammation (Figure 6D), necrosis and desquamation of the renal tubular epithelial lining and interstitial tissue hemorrhage were relatively mild in the kidney (Figure 6F), and the spleen showed pathological changes such as splenitis with diffuse fibrinoid necrosis of ellipsoids, aggregation of inflammatory cells, and accumulation of hemozoin (Figure 6H).

\section{DISCUSSION}

A. veronii is widely distributed and can be isolated from diseased aquatic animals and aquatic environments (17-19) in various countries such as Poland (20), Mexico (21), and Japan (22). The pathogen can cause human biliary sepsis and diarrhea in clinical practice $(23,24)$. The physiological and biochemical characteristics of the strain 18BJ181, such as LProline arylamidase, $\beta$-Galactosidase and O/129 resistance, were positive with $A$. veronii ATCC9071. Due to the wide variety of 


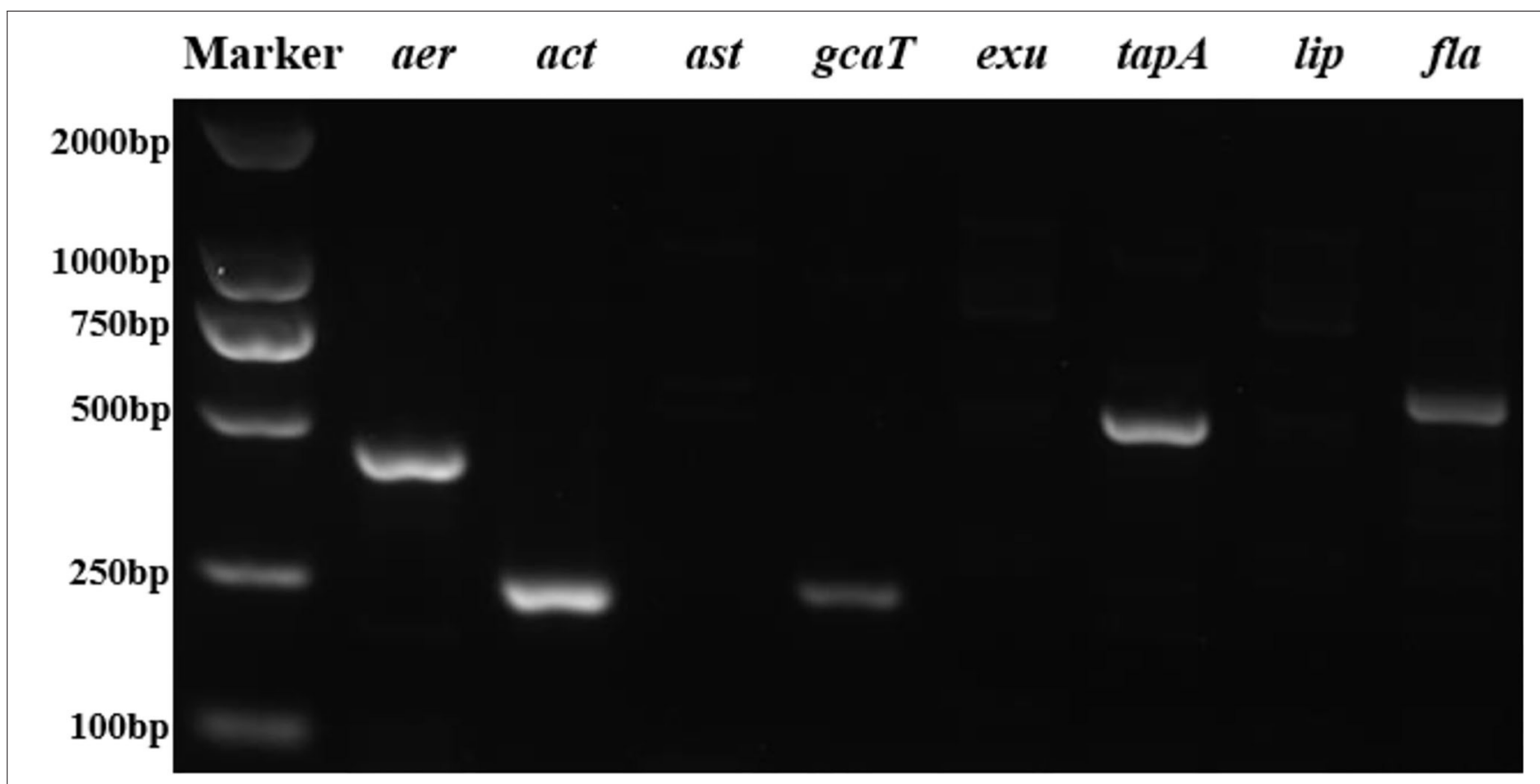

FIGURE 4 | Agarose gel electrophoresis of eight virulent genes (aer, act, ast, gcaT, exu, tapA, lip, and fla) were present in the strain $18 \mathrm{BJ} 181$.

Aeromonas species and the limited number of reactions of Vitek 2 , the molecular method is required to distinguish the species level of Aeromonas (16). 16S rRNA is one of the most commonly used molecular biological detection methods for identifying bacteria (25) and the gyrB gene has certain advantages for the identification of Aeromonas species (26). In this study, BLAST alignments showed that both $16 \mathrm{~S}$ rRNA and $g y r B$ gene sequences of the strain 18BJ181 shared the highest identities with those of other known $A$. veronii strains. The phylogenetic trees built based on the sequences of the two genes showed the strain 18BJ181 clustered with $A$. veronii strains. For the identification of $A$. veronii, it is important to use multiple molecular markers for phylogenetic analysis. If this is not possible, another approach is to conduct genomic sequence analysis for a specific strain, then combine them with epidemiological evidence for a more comprehensive analysis. Using these methods, it is possible to provide new insights into the complex evolutionary history of $A$. veronii.

A. veronii has a variety of hosts and can live in aquatic animals and in the environment, which may bring harm to aquaculture in the future. Bacterial resistance to antibiotics affects the health of animals, the environment, and humans (27). Previous research results showed that $A$. veronii was resistant to antibacterial drugs, including ampicillin, amoxicillin and oxacillin (28-31). In this study, we confirmed part of these results, specifically that strain $18 \mathrm{BJ} 181$ is resistant to amoxicillin and penicillin. Over time, $A$. veronii has developed a certain resistance to sulfamethoxazole. The results of drug sensitivity testing on the strain 18BJ181 isolate in this study provides a reference for when antimicrobials may be a potential treatment for $A$. veronii.
The pathogenicity of $A$. veronii is related to the expression of virulence factors (32). Aer is a cytotoxic pore-forming enterotoxin, which is one of the most important and abundant virulence factors of $A$. veronii. Isolates from all tissue necrosis and ulcerations in fish of $A$. veronii induced aeromonas septicemia and bacterial haemorrhagic septicemia were positive for the aer gene. The aer-positive isolates from crap fish and catfish were $52.9 \%$ and $82.4 \%$, respectively. Fish injected with $A$. veronii exhibited significantly higher mortality than carp fish $[P<0.05$, (33)]. Using an infection route via intestine, a comparison of $A$. veronii strain $\mathrm{Hm} 091$ with $A$. hydrophila showed that different expression and activity of the aer gene was the key factor that caused the difference in virulence between the two species (8). We detected the aer gene from $A$. veronii, which may have indicate a connection with its strong pathogenicity. Act gene plays an important role in $A$. hydrophila and can significantly reduce capacity to evoke fluid secretion (34). Glycerophospholipidcholesterol acyltransferase and lipases paly a common role in the pathogenicity of Aeromonas spp and, together, are secreted into the environment through the secretion system $(5,35)$. TapA of Aeromonas salmonicida participates in the process of infecting Atlantic salmon (36). The $\mathrm{fla}$ is involved in the formation of Aeromonas spp biofilms and has potential pathogenicity (37). In this study, virulence genes aer, act, gcaT, tapA and fla were detected from strain 18BJ181, but the more complex mechanism of toxicity action of $A$. veronii still needs to be further explored.

In this study, the time of death of $L$. maculatus was concentrated within $24 \mathrm{~h}$ after L. maculatus was infected by $A$. veronii infection. This finding is consistent with the death of $A$. veronii infection in Carassius auratus gibelio and Xiphophorus 


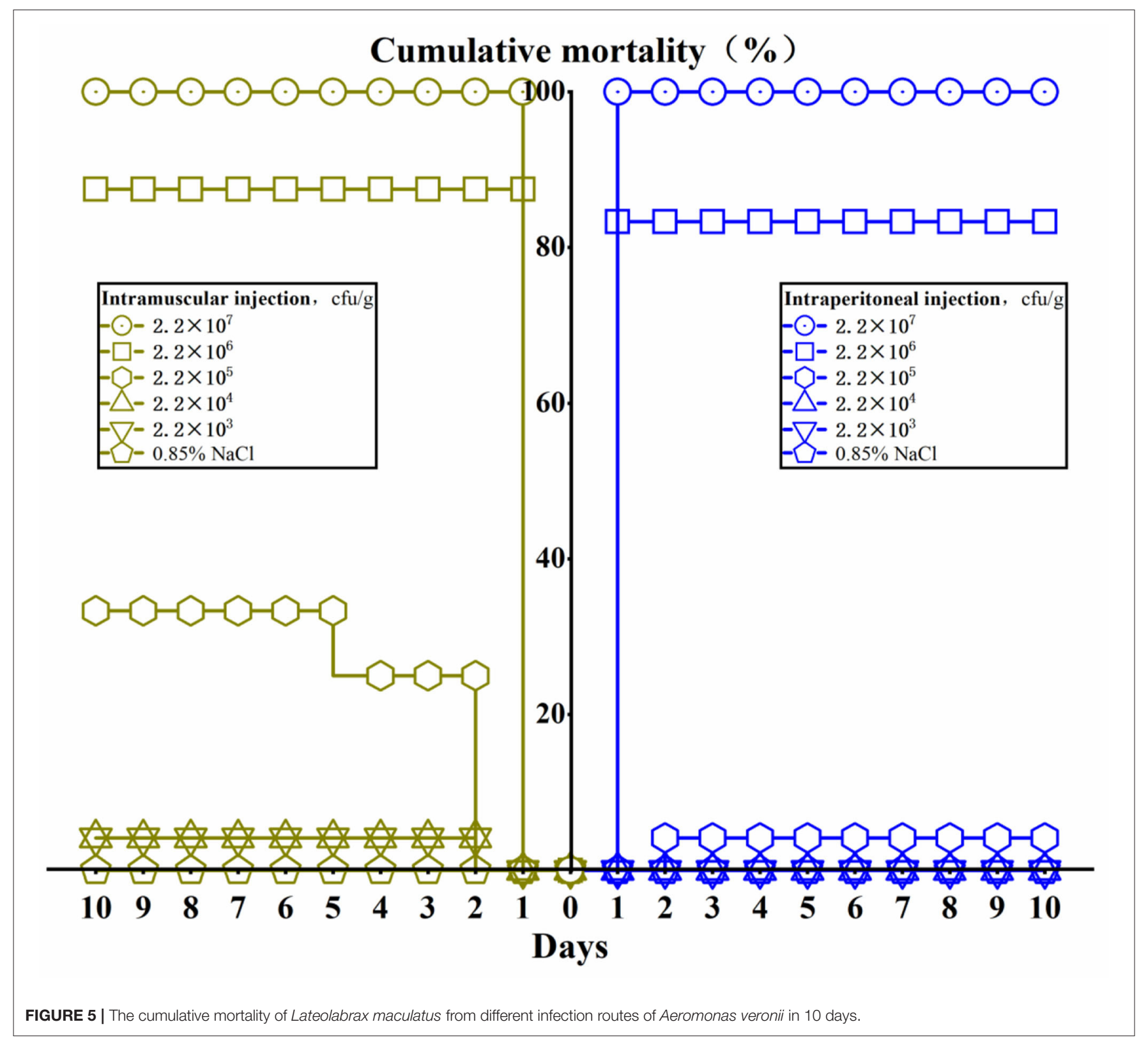

helleri $(12,38)$. This suggests that the rapid death of the host will accelerate the spread of the disease. The $\mathrm{LD}_{50}$ in the intramuscular injection group was slightly lower than in the intraperitoneal injection group, but the mortality of both showed a "cliff" decline. Zebrafish is also a susceptible host of A. veronii. It has been found that this fish can be successfully infected with $A$. veronii through different infection routes (8). Likewise, A. hydrophila showed muscle liquefaction and furuncle lesions in infected rainbow trout (Oncorhynchus mykiss) after intramuscular injection (39). The difference in the expression and activity of the aer gene between $A$. veronii and $A$. hydrophila resulted in $A$. veronii being slightly more virulent than $A$. hydrophila, and this in turn activates the activity of the aer gene and functions in enhancing the adhesion ability of bacteria in host cells (8). In addition, the quorum-sensing system plays a key role in the infection of $A$. veronii and is a major metabolic regulator in $A$. veronii and participating in sturgeon spoilage (40). This is related to the quorum-sensing system of $A$. veronii and $A$. hydrophila in regulating virulence in catfish (41). The virulence regulation effect of Aeromonas on burbot (Lota Lota) was also regulated by quorum sensing (42). N-acyl homoserine lactone (AHL) mediated by the quorum-sensing mechanisms may be involved in regulating the type VI secretion system (T6SS), metalloprotease production, biofilm formation, and virulence of A. veronii (43). As previously reported, AHL molecules are not only involved in bacterial virulence regulation but also interact with several eukaryotic cells and play function in the immunomodulation of the host response in Pseudomonas aeruginosa (44). 


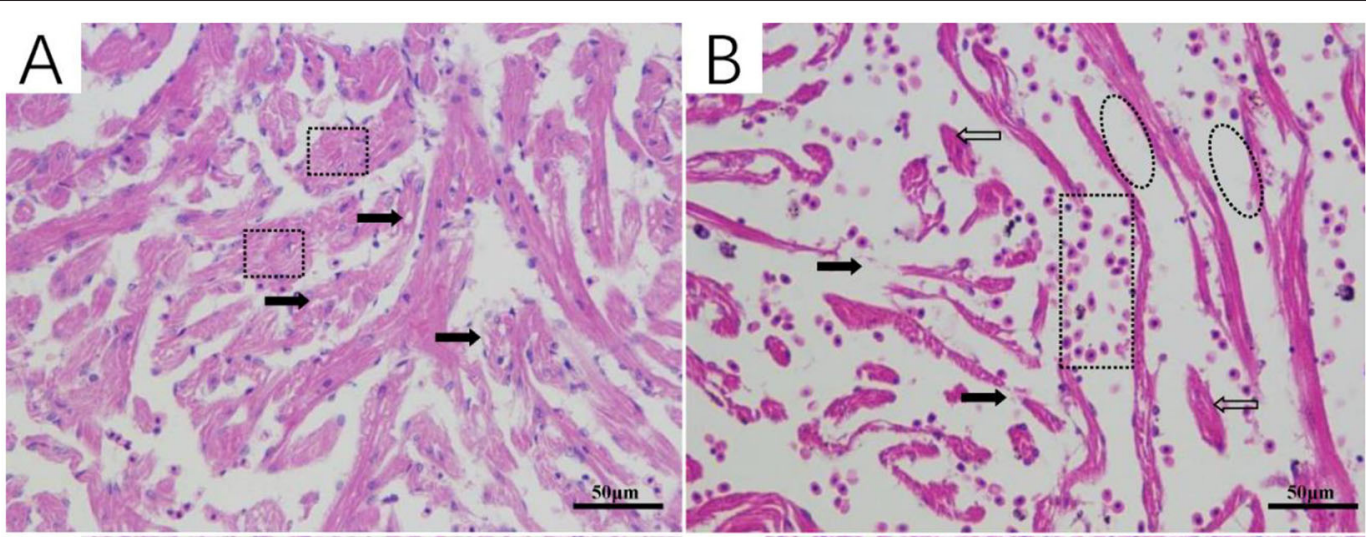

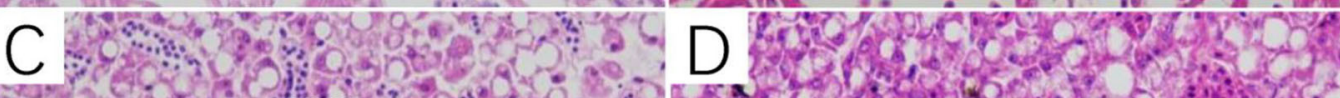

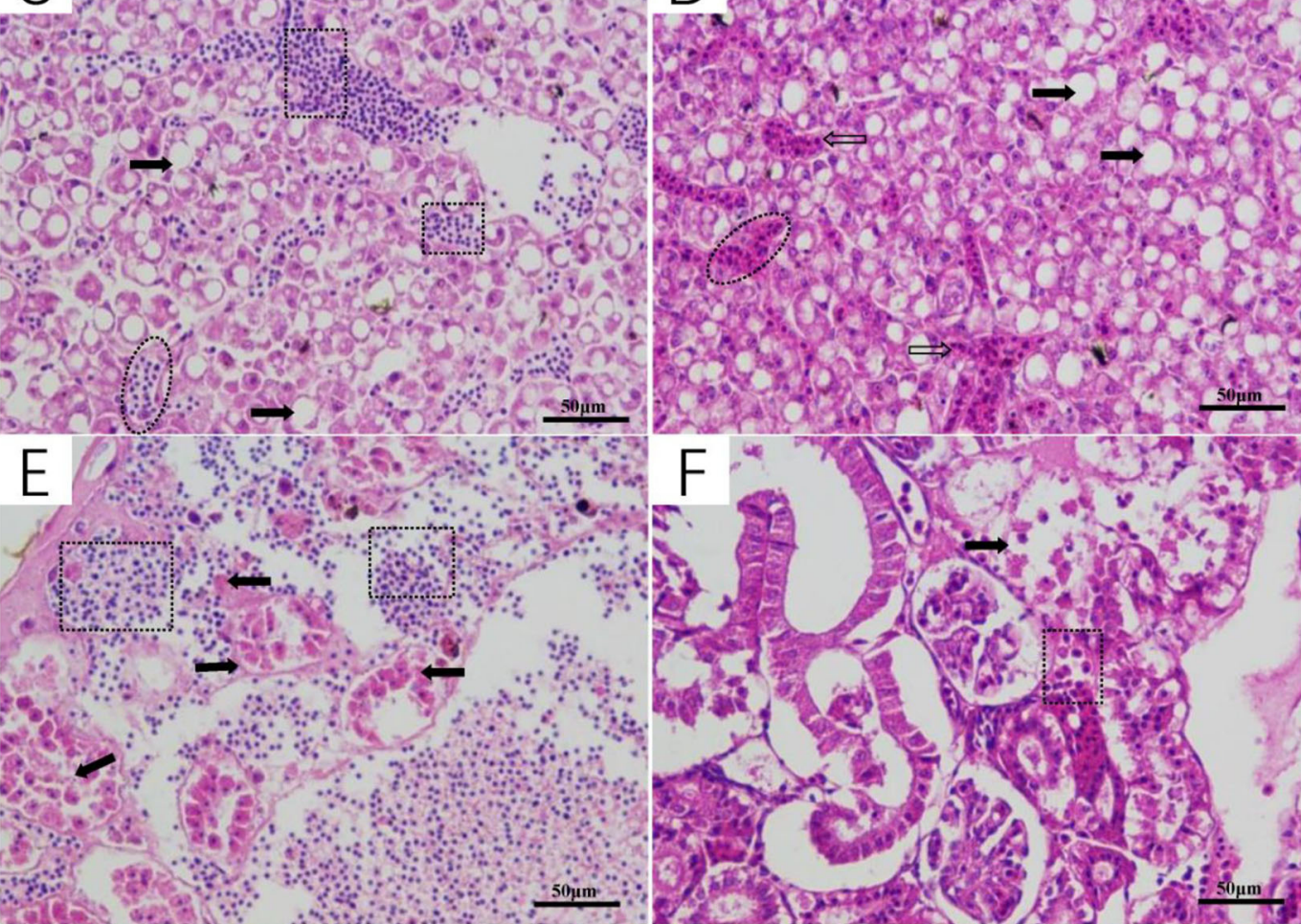

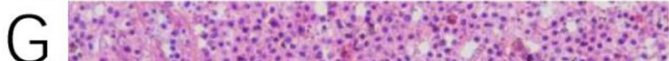

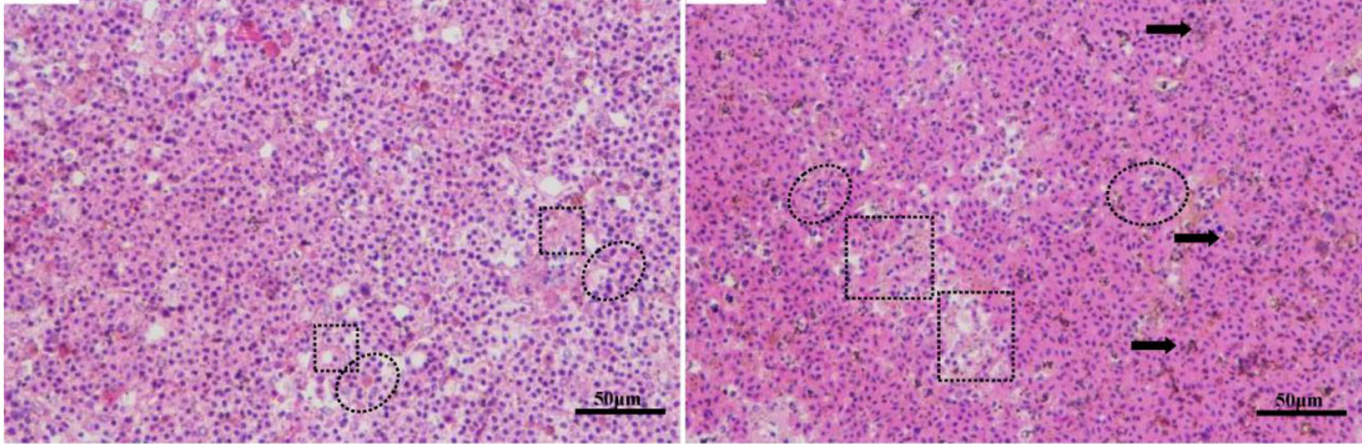

FIGURE 6 | Histopathological changes of Lateolabrax maculatus with artificial infection of Aeromonas veronii (A,C,E,G: intraperitoneal injection, B,D,F,H

intramuscular injection). Cardiomyocyte vacuolization (solid arrows) with myofibrillar degeneration (rectangular) (A) and myocardial hemorrhage (rectangular) with

(Continued) 
FIGURE 6 | myofibrillar edema (ovals), rupture (solid arrows) and necrosis (hollow arrows) (B). Hepatocellular steatosis (solid arrows), congestion (ovals), hemorrhage (rectangular), and inflammation (hollow arrows) in the liver (C,D). Kidney with marked necrosis and desquamation of the renal tubular epithelial lining leaving the basement membrane (solid arrows) notice the hemorrhage in the interstitial tissue (rectangular) (E,F). Moderate splenitis with numerous lymphocytes and macrophages aggregated around ellipsoids (ovals) in addition to an accumulation of proteinaceous substance (rectangular) (G). Splenitis with diffuse fibrinoid necrosis of ellipsoids (rectangular), aggregation of inflammatory cells (ovals), and hemozoin accumulation (solid arrows) (H).

However, the exact mechanism of action is unclear. L. maculatus infected with $A$. veronii died acutely in a short period of time and correlated with the concentration of infection. This indicates that it may be closely related to the quorum-sensing system, but the details still need to be further studied.

Aeromonas can cause an infection characterized by septicemia and spread within 1 hpi through the organs, affecting irreversible lesions to the liver, kidney and spleen. The pathogen was detected in the spleen at $3 \mathrm{hpi}$, and the greatest amounts of Aeromonas and lesions were observed at 6 and 9 hpi in all evaluated organs $(p<0.05)$ (45). Aeromonas infection of fish also cause skin ulcers, intra-abdominal hemorrhage, and other clinical symptoms. Interestingly, there are a variety of symptoms caused by different types of Aeromonas infections (15). For example, the clinical signs of bacterial septicemia in catfish caused by A. veronii were pale gills, slight abdominal distension, and swollen and inflamed vents (46). When $A$. veronii infect Sheatfish, petechial skin hemorrhages appear, as well as ascitic distension of the abdomen, redness, and swelling of the anus (47). A. veronii can cause histopathological changes such as hemorrhage, congestion, and ulcers in different organs (6). Some cases of A. veronii infected fish showed degenerative histopathological changes such as cellular vacuolation, intravascular congestion, and cell necrosis (3). In this study, the histopathological results were similar to those of previous studies. For example, in some internal organs there were histopathological changes, especially the necrosis of the renal tubular epithelial lining and interstitial tissue hemorrhage. These symptoms provided direct evidence of the cause of death in L. maculatus.

In conclusion, this is the first study to report a case of $A$. veronii infection in L. maculatus in China. Clinical symptoms of naturally infected fish were acute death, ulceration on the body surface, congestion, and hemorrhages in internal organs. A. veronii is resistant to amoxicillin, madinomycin, and other antimicrobial agents and is suitable for survival in the environment. Using artificial infection, A. veronii can infect $L$. maculatus through intraperitoneal injection and intramuscular injection, causing abdominal hemorrhage and congestion, as well as pathological damage to the heart, liver, kidney, and spleen

\section{REFERENCES}

1. Fernandez-Bravo A, Fort-Gallifa I, Ballester F, Pujol I, GomezBertomeu F, Dominguez M, et al. A case of Aeromonas trota in an immunocompromised patient with diarrhea. Microorganisms. (2020) 8:399. doi: 10.3390/microorganisms8030399

2. Shameena SS, Kumar K, Kumar S, Kumar S, Rathore G. Virulence characteristics of Aeromonas veronii biovars isolated from infected including degeneration, necrosis, and hemorrhage. As a newly reported bacterial disease in L. maculatus, this report sheds new light on understanding the characteristics of $A$. veronii regarding host pathogenicity. Further epidemiological investigation and retrospective studies are needed, as well as further exploration of the relationship between pathogenic bacteria and the host.

\section{DATA AVAILABILITY STATEMENT}

The datasets presented in this study can be found in online repositories. The names of the repository/repositories and accession number(s) can be found in the GenBank: MW362188 for Aeromonas veronii strain 18BJ181 16S ribosomal RNA gene and MW371213 for Aeromonas veronii strain 18BJ181 gyrB gene partial cds, respectively.

\section{ETHICS STATEMENT}

The animal study was reviewed and approved by the Animal Care and Use Committee of Zhongkai University of Agriculture and Engineering.

\section{AUTHOR CONTRIBUTIONS}

YS and BW conceived and designed as well as analyzed the experiments. BW performed all the experiments and wrote the paper. CM completed the Antimicrobial resistance test. JH, YL, and QG assisted in laboratory experiments and data analysis. JF, $\mathrm{BJ}$, and YS participated in discussions and revisions and critically examines the final uploaded manuscripts. All authors read and agreed to the final version of the manuscript.

\section{FUNDING}

This work was supported by grants from the Central Publicinterest Scientific Institution Basal Research Fund, South China Sea Fisheries Research Institute, CAFS (2018ZD01) and the Key Project of Department of Education of Guangdong Province (2019KZDXM043). freshwater goldfish (Carassius auratus). Aquaculture. (2020) 518:734819. doi: 10.1016/j.aquaculture.2019.734819

3. El Latif AMA, Elabd H, Amin A, Eldeen AIN, Shaheen AA. High mortalities caused by Aeromonas veronii:identification, pathogenicity, and histopathologicalstudies in Oreochromis niloticus. Aquaculture Int. (2019) 27:1725-37. doi: 10.1007/s10499-019-00429-8

4. Cai SH, Wu ZH, Jian JC, Lu YS, Tang JF. Characterization of pathogenic Aeromonas veronii bv. Veronii associated with ulcerative syndrome from 
chinese longsnout catfish (Leiocassis longirostris Gunther). Braz J Microbiol. (2012) 43:382-8. doi: 10.1590/S1517-838220120001000046

5. Nawaz M, Khan SA, Khan AA, Sung K, Tran Q, Kerdahi K, et al. Detection and characterization of virulence genes and integrons in Aeromonas veronii isolated from catfish. Food Microbiol. (2010) 27:327-31. doi: 10.1016/j.fm.2009.11.007

6. Hoai TD, Trang TT, Van Tuyen N, Giang NTH, Van Van K. Aeromonas veronii caused disease and mortality in channel catfish in Vietnam. Aquaculture. (2019) 513:734425. doi: 10.1016/j.aquaculture.2019.734425

7. Zepeda-Velázquez AP, Vega-Sánchez V, Salgado-Miranda C, Soriano-Vargas E. Histopathological findings in farmed rainbow trout (Oncorhynchus mykiss) naturally infected with 3 different Aeromonas species. Can J Vet Res. (2015) 79:250-4.

8. Ran C, Qin C, Xie M, Zhang J, Li J, Xie Y, et al. Aeromonas veronii and aerolysin are important for the pathogenesis of motile aeromonad septicemia in cyprinid fish. Environ Microbiol. (2018) 20:3442-56. doi: $10.1111 / 1462-2920.14390$

9. Tian Y, Wen H, Qi X, Mao X, Shi Z, Li J, et al. Analysis of apolipoprotein multigene family in spotted sea bass (Lateolabrax maculatus) and their expression profiles in response to Vibrio harveyi infection. Fish Shellish Immunol. (2019) 92:111-8. doi: 10.1016/j.fsi.2019.06.005

10. Austin B, Zhang XH. Vibrio harveyi: a significant pathogen of marine vertebrates and invertebrates. Lett Appl Microbiol. (2006) 43:119-24. doi: 10.1111/j.1472-765X.2006.01989.x

11. Han YL, Hou CC, Du C, Zhu JQ. Molecular cloning and expression analysis of five heat shock protein 70 (HSP70) family members in Lateolabrax maculatus with Vibrio harveyi infection. Fish Shellfish Immunol. (2017) 60:299-310. doi: 10.1016/j.fsi.2016.11.056

12. Han Z, Sun J, Lv A, Sung Y, Shi H, Hu X, et al. Isolation, identification and characterization of Shewanella algae from reared tongue sole, Cynoglossus semilaevis Günther. Aquaculture. (2017) 468:356-62. doi: 10.1016/j.aquaculture.2016.10.038

13. Pate JB, Tenover FC, Turnidge JD, Jorgensen JH. Susceptibility test methods: dilution and disk diffusion methods. In: Manual of Clinical Microbiology. (2011). p. 1122-43. doi: 10.1128/9781555816728.ch68

14. Li S, Chen X, Chen Y. Distribution characteristics and virulence gene analysis of intestinal and extraintestinal Aeromonas. Chin J Clin Lab Sci. (2017) 35:503-6. doi: 10.13602/j.cnki.jcls.2017.07.06

15. Chen F, Sun J, Han Z, Yang X, Xian JA, Lv A, et al. Isolation, identification and characteristics of Aeromonas veronii from diseased crucian carp (Carassius auratus gibelio). Front Microbiol. (2019) 10:2742. doi: $10.3389 /$ fmicb.2019.02742

16. Chen J, Zhu N, Kong L, Bei Y, Zheng T, Ding X, et al. First case of soft shell disease in Chinese soft-shelled turtle (Trionyx sinens) associated with Aeromonas sobria-A. veronii complex. Aquaculture. (2013) 406-407:62-7. doi: 10.1016/j.aquaculture.2013. 05.006

17. Lye DJ. Gastrointestinal colonization rates for human clinical isolates of Aeromonas veronii using a mouse model. Curr Microbiol. (2011) 63:332-6. doi: 10.1007/s00284-011-9982-5

18. Weiss G, Kovalerchick D, Lieman-Hurwitz J, Murik O, De Philippis $\mathrm{R}$, Carmeli S, et al. Increased algicidal activity of Aeromonas veronii in response to Microcystis aeruginosa: interspecies crosstalk and secondary metabolites synergism. Environ Microbiol. (2019) 21:1140-50. doi: 10.1111/1462-2920.14561

19. Weiss G, Kovalerchick D, Murik O, Sukenik A, Kaplan A, Carmeli S. Secondary metabolites of aeromonas veronii strain a134 isolated from a microcystis aeruginosa bloom. Metabolites. (2019) 9:110. doi: $10.3390 /$ metabo 9060110

20. Dworaczek K, Drzewiecka D, Pekala-Safinska A, Turska-Szewczuk A. Structural and serological studies of the O6-related antigen of Aeromonas veronii bv. sobria strain $\mathrm{K} 557$ isolated from Cyprinus carpio on a polish fish farm, which contains L-perosamine (4-amino-4,6-dideoxy-L-mannose), a unique sugar characteristic for Aeromonas serogroup O6. Mar Drugs. (2019) 17:399. doi: 10.3390/md17070399

21. Reyes-Becerril M, Sanchez V, Delgado K, Guerra K, Velazquez E, Ascencio F, et al. Caspase- $1,-3,-8$ and antioxidant enzyme genes are key molecular effectors following Vibrio parahaemolyticus and Aeromonas veronii infection in fish leukocytes. Immunobiology. (2018) 223:562-76. doi: 10.1016/j.imbio.2018.07.002

22. De SJSS, Honein K, Arulkanthan A, Ushio H, Asakawa S. Genome sequencing and annotation of Aeromonas veronii strain Ae52, a multidrug-resistant isolate from septicaemic gold fish (Carassius auratus) in Sri Lanka. Genom Data. (2017) 11:46-8. doi: 10.1016/j.gdata.2016.11.011

23. Ottaviani D, Leoni F, Rocchegiani E, Santarelli S, Masini L, D’Annibale ML, et al. A severe case of Aeromonas veronii biovar sobria travellers' diarrhoea characterized by Vibrio parahaemolyticus co-isolation. Med Microbiol. (2013) 62(Pt 1):161-4. doi: 10.1099/jmm.0.044743-0

24. Monti M, Torri A, Amadori E, Rossi A, Bartolini G, Casadei C, et al. Aeromonas veronii biovar veronii and sepsis-infrequent complication of biliary drainage placement: a case report. World J Clin Cases. (2019) 7:759-64. doi: 10.12998/wjcc.v7.i6.759

25. Busse HJ, Denner EB, Lubitz W. Classification and identification of bacteria: current approaches to an old problem. Overview of methods used in bacterial systematics. Biotechnology. (1996) 47:3-38. doi: 10.1016/0168-1656(96)01379-x

26. Kasai H, Watanabe K, Gasteiger E, Bairoch A, Isono K, Yamamoto S, et al. Construction of the gyrB database for the identification and classification of bacteria. Genome Inform Int Conference on Genome Inform. (1998) 9:13-21. doi: 10.11234/gi1990.9.13

27. Wu J, Su Y, Deng Y, Guo Z, Mao C, Liu G, et al. Prevalence and distribution of antibiotic resistance in marine fish farming areas in Hainan, China. Sci Total Environ. (2019) 653:605-11. doi: 10.1016/j.scitotenv.2018.10.251

28. Nawaz M, Sung K, Khan SA, Khan AA, Steele R. Biochemical and molecular characterization of tetracycline-resistant Aeromonas veronii isolates from catfish. Appl Environ Microbiol. (2006) 72:6461-6. doi: 10.1128/AEM.00271-06

29. Jacobs L, Chenia HY. Characterization of integrons and tetracycline resistance determinants in Aeromonas spp. isolated from South African aquaculture systems. Int J Food Microbiol. (2007) 114:295-306. doi: 10.1016/j.ijfoodmicro.2006.09.030

30. Koksal F, Oguzkurt N, Samasti M, Altas K. Prevalence and antimicrobial resistance patterns of Aeromonas strains isolated from drinking water samples in istanbul, Turkey. Chemotherapy. (2007) 53:30-5. doi: 10.1159/000098248

31. Zhixiu Z, Xinhua J, Shunzhou D, Bei W, Huihong L. Isolation, identification and in vitro antimicrobial susceptibility of pathogenic aeromonas veronii from soft-shelled turtles. Agric Sci Technol. (2016) 17:804-9. doi: 10.16175/j.cnki.1009-4229.2016.04.009

32. Song M, Zhang D, Zhang H, Long C, YuanHuan K, Lei Z, et al. Research advances of virulence factors in Aeromonas veronii. Chin Vet Sci. (2018) 48:1038-42. doi: 10.16656/j.issn.1673-4696.2018.0152

33. Foysal MJ, Momtaz F, Ali MH, Siddik MAB, Chaklader MR, Rahman MM, et al. Molecular characterization and interactome analysis of aerolysin (aer) gene from fish pathogen Aeromonas veronii: The pathogenicity inferred from sequence divergence and linked to histidine kinase (cheA). J Fish Dis. (2019) 42:465-75. doi: 10.1111/jfd.12954

34. Sha J, Kozlova EV, Chopra AK. Role of various enterotoxins in Aeromonas hydrophila-induced gastroenteritis: generation of enterotoxin gene-deficient mutants and evaluation of their enterotoxic activity. Infect Immun. (2002) 70:1924-35. doi: 10.1128/iai.70.4.1924-1935.2002

35. Lee KK, Ellis AE. Glycerophospholipid:cholesterol acyltransferase complexed with lipopolysaccharide (LPS) is a major lethal exotoxin and cytolysin of Aeromonas salmonicida: LPS stabilizes and enhances toxicity of the enzyme. $J$ Bacteriol. (1990) 172:5382-93.

36. Boyd JM, Dacanay A, Knickle LC, Touhami A, Brown LL, Jericho MH, et al. Contribution of Type IV Pili to the Virulence of Aeromonas salmonicida subsp. salmonicida in Atlantic Salmon (Salmo salar L). Infect Immun. (2008) 76:1445-55. doi: 10.1128/iai.01019-07

37. Freire NB, Magalhães TC, Nunes Soares RA, da Costa MM, Gouveia GV. Nutritional interference for phenotypic biofilm quantification in Aeromonas spp. isolates containing the fla gene. Microb Pathog. (2019) 127:198-201. doi: 10.1016/j.micpath.2018.11.044

38. Das S, Aswani R, Jasim B, Sebastian KS, Radhakrishnan EK, Mathew J. Distribution of multi-virulence factors among Aeromonas spp. isolated from diseased Xiphophorus hellerii. Aquac Int. (2019) 28:235-48. doi: 10.1007/s10499-019-00456-5 
39. Orozova P, Barker M, Austin DA, Austin B. Identification and pathogenicity to rainbow trout, Oncorhynchus mykiss (Walbaum), of some aeromonads. $J$ Fish Dis. (2009) 32:865-71. doi: 10.1111/j.1365-2761.2009.01065.x

40. Talagrand-Reboul E, Jumas-Bilak E, Lamy B. The social life of Aeromonas through biofilm and quorum sensing systems. Front Microbiol. (2017) 8:37. doi: 10.3389/fmicb.2017.00037

41. Tekedar HC, Kumru S, Blom J, Perkins AD, Griffin MJ, Abdelhamed $\mathrm{H}$, et al. Comparative genomics of Aeromonas veronii: identification of a pathotype impacting aquaculture globally. PLoS ONE. (2019) 14:e0221018. doi: 10.1371/journal.pone.0221018

42. Natrah FMI, Alam MI, Pawar S, Harzevili AS, Nevejan N, Boon N, et al. The impact of quorum sensing on the virulence of Aeromonas hydrophila and Aeromonas salmonicida towards burbot (Lota lota L.) larvae. Vet Microbiol. (2012) 159:77-82. doi: 10.1016/j.vetmic.2012. 03.014

43. Khajanchi BK, Sha J, Kozlova EV, Erova TE, Suarez G, Sierra JC, et al. $\mathrm{N}$-acylhomoserine lactones involved in quorum sensing control the type VI secretion system, biofilm formation, protease production, and in vivo virulence in a clinical isolate of Aeromonas hydrophila. Microbiology. (2009) 155(Pt 11):3518-31. doi: 10.1099/mic.0.03 1575-0

44. Liu YC, Chan KG, Chang CY. Modulation of host biology by Pseudomonas aeruginosa quorum sensing signal molecules: messengers or traitors. Front Microbiol. (2015) 6:1226. doi: 10.3389/fmicb.2015. 01226
45. Marinho-Neto FA, Claudiano GS, Yunis-Aguinaga J, CuevaQuiroz VA, Kobashigawa KK, Cruz NRN, et al. Morphological, microbiological and ultrastructural aspects of sepsis by Aeromonas hydrophila in Piaractus mesopotamicus. PLoS ONE. (2019) 14:e0222626. doi: 10.1371/journal.pone.0222626

46. Mohammed HH, Peatman E. Winter kill in intensively stocked channel catfish (Ictalurus punctatus): coinfection with Aeromonas veronii, Streptococcus parauberis and Shewanella putrefaciens. J Fish Dis. (2018) 41:1339-47. doi: $10.1111 /$ jfd.12827

47. Xiucai H, Xiaoxue L, Aijun L, Jingfeng S, Yajiao S. Characterization and pathology of Aeromonas veronii biovar sobria from diseased sheatfish Silurus glanis in China. Isr J Aquacult-Bamid. (2019) 71:11. Available online at: http:// hdl.handle.net/10524/61076

Conflict of Interest: The authors declare that the research was conducted in the absence of any commercial or financial relationships that could be construed as a potential conflict of interest.

Copyright (C) 2021 Wang, Mao, Feng, Li, Hu, Jiang, Gu and Su. This is an open-access article distributed under the terms of the Creative Commons Attribution License (CC BY). The use, distribution or reproduction in other forums is permitted, provided the original author(s) and the copyright owner(s) are credited and that the original publication in this journal is cited, in accordance with accepted academic practice. No use, distribution or reproduction is permitted which does not comply with these terms. 